\title{
Kolik času zameškají žáci v českém základním školství?
}

\author{
Eva Skalová, Dominik Dvořák
}

\begin{abstract}
Abstrakt: Cíle. Absence žákủ ve škole je závažným jevem s dopadem na žáka i školu. V českém školstvi dosud prevládaly prakticky orientované prístupy zaměrené na řešeni prípadù častých neomluvených absenci - záškoláctví. V zahraničnich vzdèlávacích systémech roste pozornost, která je věnována sledováni, predcházení nebo zmirnvováni dopadü zvýsené celkové absence žákü bez ohledu na jeji príčiny. Nás článek si proto klade dva cíle: zaprvé ukazujeme, jak se vymezuje v zahraniči tzv. chronická absence, zadruhé hledáme odhad prümèrné celkové absence v českých základních školách.

Metody. Provedli jsme explorativni analyzu otevrených dat z činnosti České školni inspekce (záznamy o 11625 hospitovaných hodinách) a pilotnich mikrodat z velké základni školy ( $N=957$ žákư).

Výsledky. Naše analýza naznačuje, že jak prümèrná celková absence (12\% na prvnim stupni a $13 \%$ na druhém stupni základnich škol), tak chronická absence - podil žákù s velkými počty zamě̌kaných hodin - by mohly $v$ Česku být poměrně vysoké.

Závěry. Téma by mèlo být dále podrobnèji sledováno jak výzkumníky, tak tvưrci vzdèlávací politiky. Při tom je třeba pracovat s vice rüznými indikátory nežs dosud prevažujicím vykazovánim absolutniho počtu zameškaných hodin.
\end{abstract}

Klićová slova: absence, záškoláctví, otevřená data, administrativni data, Česká republika.

Zabývat se absencemi je důležité ze tří hlavních důvodů (Dougherty, 2018): 1. Př́ítomnost žáka ve škole (pravidelná docházka) sama o sobě je důležitá - předpokládá se, že je jedním z důležitých ukazatelů tzv. příležitosti $\mathrm{k}$ učení. Když žák ve škole není, nemá příležitost se učit z výuky. Samozřejmě to není jediný faktor - i když žák na výuce je, ještě to není záruka, že učení skutečně probíhá (Knecht, 2014). 2. Docházka, resp. absence, záškoláctví a podobné jevy se považují za indikátor (resp. proxy) vztahu žáka ke škole (engagement with schooling) a souvisejí- cích jevů. 3. Pravidelná docházka se stává v poslední době také důležitým a svébytným postojovým výstupem vzdělávání na základě předpokladu o potřebnosti odpovídajících návyků pro úspěch na další životní dráze; můžeme obecněji říci, že jde o jeden $z$ projevů většího důrazu na non-kognitivní úkoly vzdělávání obecně.

Docházka proto zajímá - nebo by měla zajímat - jak učitele a ředitele, rodiče, sociální pracovníky, pediatry, tak i výzkumníky a tvůrce vzdělávací politiky. $\mathrm{V}$ zahraničí skutečně existuje velké množství výzkumů i prakticky orientovaných ma- 
teriálů na toto téma. Tradičně mu věnují pozornost školní i kliničtí psychologové a pedopsychiatři, protože zvýšená míra absencí souvisí $s$ řadou poruch prožívání a chování (Finning et al., 2019a; Kearney et al., 2019a). Ukazuje se však, že př́istupy různých profesí a skupin aktérů $\mathrm{k}$ problematice absencí se velmi liší, takže velmi odlišně konceptualizují a operacionalizují i sám jev. Dohledat proto data, byt' i jen popisná, která by $\mathrm{z}$ hlediska absencí $\mathrm{v}$ rámci povinné školní docházky charakterizovala různé země světa, různé skupiny žáků nebo dokonce různé typy lokalit $\mathrm{v}$ rámci těchto zemí, se však ukázalo - s některými výjimkami - jako velmi obtížné.

V českém prostředí jsme se na počátku roku 2020 stali svědky vlny mediálního zájmu o záškoláctví, $\mathrm{k}$ níž přispěly mj. otevřený dopis starosty východočeské Úpice a ředitele místní školy o problematice absentérství zaslaný poslancům, ale hlavně návrh ministryně práce a sociálních věcí J. Maláčové sankcionovat rodiče „záškolákư“ snižováním dávek na bydlení (Hromková \& Janouš, 2000). Tyto události potvrdily předchozí signály České školní inspekce (2015), že absence jsou i v Česku závažným problémem. Současně se ukázalo, že chybí koncepční príistup k tomuto problému. Po kritice ze strany části odborné veřejnosti se diskuse od postihů posunula ke konceptu tzv. školní sociální práce. Výzkum absencí by však neměl být redukován na skryté či zjevné záškoláctví ani spojován $s$ jednou skupinou žáků. Vysoké absence mohou být způsobeny řadou odlišných příčin - a výzkum ukazuje, že zejména prríčiny na straně školy bývají pod- ceňovány (Finning et al., 2018, 2019b). $\mathrm{Na}$ žákovu vzdělávací dráhu však mohou mít závažné a trvalé dopady i vysoké absence ze zdravotních a obdobných důvodů, a i zde je třeba včas problém zachytit a hledat vhodné strategie intervence.

Absentérstvím se nedávno zabývali Hlado a Šlapalová (2019), jejich práce se však zaměruje na střední odborné školství, kde se problematika docházky a absence v mnoha ohledech liší od nižších stupňů vzdělávání, mj. v důsledku odlišného stadia fyzického, psychického i sociálního vývoje žáků středních škol a v neposlední řadě také kvůli již ukončené povinné školní docházce a často i zletilosti. Citovaní autoři přistupují ke zkoumání absence výlučně kvalitativně a z perspektivy žáka samého. Nalezli jsme starší studie ze šedesátých let 20. století, kdy lékař Miroslav Chlup (1962) provedl několik výzkumů absence a zdravotního stavu žactva, ale vzhledem $\mathrm{k}$ odlišným standardům prezentování empirických dat $\mathrm{v}$ minulosti a dnes je jejich využitelnost omezená. Specifickou otázku dlouhodobých hospitalizací při chronické nemoci dětí a jejich dopadu na vzdělávání připomněli v poslední době Mareš a Žofka (2016).

Našim cílem je: 1. popsat různé príistupy ke konceptualizaci a měření absence na úrovni žáka, školy a vzdělávacího systému; 2. ukázat, jakých hodnot dosahují míry chronické absence $\mathrm{v}$ anglickém a americkém školském systému, pro něž jsou $\mathrm{k}$ dispozici odpovídající údaje; 3. explorativní analýzou dostupných, resp. pilotních dat odhadnout tyto míry pro české školství. 


\section{Co VÍME O Míře ABSENCÍ}

$\mathrm{V}$ tomto oddíle nejprve provedeme stručné terminologické a konceptuální vymezení jevů vztahujících se $\mathrm{k}$ docházce obecně. Pak na pŕíkladu dvou vzdělávacích systémů - Anglie a Spojených států amerických - popíšeme způsoby a výsledky měření absencí.

\subsection{Základní jevy a jejich terminologie}

Tabulka 1 shrnuje základní terminologii užívanou v češtině a v mezinárodní literatuře pro nepř́tomnost žáka ve škole. ${ }^{1}$ Dalšími výrazy, jež mohou sloužit pro vyhledávání literatury, jsou neprítomný žák (absentee), prŕípadně záškolák (truant). Termín enrolment/non-enrolment ( $\mathrm{v}$ americké angličtině enrollment) se někdy používá ve smyslu počet skutečně prítomných žáků v hodině (srov. 2.1), i když často znamená podíl žáků $\mathrm{z}$ určité skupiny zapsaných na předmět nebo do určitého typu školy. Terminologická neustálenost dost komplikuje pokusy o přesné definice a hlavně měření jednotlivých druhů absencí. Zjednodušeně se předpokládá, že zatímco omluvené absence se týkají především zdravotního stavu (dlouhodobá nemoc, úraz) a vnějších okolností, neomluvené absence souvisejí převážně se sociálními podmínkami, prostředím, psychickým stavem žáka atd. Konceptualizaci absence se věnují i Šlapalová a Hlado (2020).

Tab. 1. Terminologie vztahující se $\mathrm{k}$ absenci

\begin{tabular}{|c|c|c|c|}
\hline \multicolumn{2}{|c|}{ Anglický termín } & \multicolumn{2}{|c|}{ Český termín } \\
\hline \multirow{4}{*}{$\begin{array}{l}\text { absence } \\
\text { non-attendance } \\
\text { missed class/day }\end{array}$} & excused/excusable & \multirow{4}{*}{$\begin{array}{l}\text { absence } \\
\text { neprítomnost } \\
\text { zameškaná hodina/den }\end{array}$} & omluvená \\
\hline & unexcused/inexcusable & & neomluvená \\
\hline & suspension, expulsion & & $\begin{array}{l}\text { vyloučení z vyučovací } \\
\text { hodiny }\end{array}$ \\
\hline & & & nezapočtená \\
\hline \multicolumn{2}{|l|}{ truancy } & \multicolumn{2}{|l|}{ záśkoláctví } \\
\hline \multicolumn{2}{|c|}{ chronic/persistent absenteeism } & \multicolumn{2}{|l|}{ (chronické) absentérství } \\
\hline \multicolumn{2}{|l|}{ tardiness, lateness } & \multicolumn{2}{|c|}{$\begin{array}{l}\text { pozdní prííchod(y) do školy nebo vyučovací } \\
\text { hodiny } \\
\text { nedochvilnost }\end{array}$} \\
\hline
\end{tabular}

Pozn.: Doba, kdy je žák dočasně vyloučen z výuky, není u nás chápána jako absence, protože škola je povinna zajistit vzdělávání žáka jinou formou (MŠMT, 2014).

${ }^{1}$ Někdy se i v odborné (anglické) literatuře lze setkat s termíny jako skipping school, cutting class. Hovorová angličtina a slangy mají mnoho dalších výrazů, podle Wikipedie se v Austrálii a na Novém Zélandu užívá wagging, jigging, ditching, v britské angličtině taky bobbing, bunking (off), skiving aj. 
V českém prostředí se často setkáváme $s$ termínem záškoláctví (truancy). Záškoláctví je definováno jako určitý počet nebo určitá četnost neomluvených hodin, „kdy se žák úmyslně bez omluvitelného důvodu nezúčastní školní výuky" (Kašpárková, 2009 , s. 73). V současnosti jsou na národní úrovni za kritické považovány hodnoty 10 , resp. 25 hodin neomluvené nepřítomnosti (MŠMT, 2002, 2017). Vnitřní praxe škol v přístupu k neomluveným absencím se však značně liší (Bendl et al., 2018). Záškoláctví, zejména ve svých extrémních podobách, je také způsobem, jak problematika absencí bývá prezentována $\mathrm{v}$ českém denním tisku.

V praxi ovšem existuje fenomén skrytého záškoláctví, kdy rodiče nebo škola omlouvají absence, které by jinak spadaly do kategorie neomluvených. Právě proto je v zahraničí velká pozornost věnována celkové absenci každého žáka a na úrovni školy pak podílu žáků, u nichž celková absence přesáhne určitou mez - pak se mluví o perzistentní nebo chronické absenci. Nepř́tomnost $\mathrm{v}$ hodinách má negativní vliv na výkon ve škole, at už je omluvená, nebo nikoli. Neúčast ve škole je spolehlivým prediktorem selhání ve škole, a pokud žák již ukončil povinnou školní docházku, chronická absence zvyšuje pravděpodobnost předčasného odchodu ze školy nebo vzdělávání. Včasné zaznamenání zvýšené míry absencí umožňuje včasnou identifikaci rizikových žáků, než postoupí do dalších ročníků, kde mohou být zesíleny problémy jak v oblasti učení, tak - pokud celková omluvená absence maskuje záškoláctví - problémy s chováním. Chronická absence tedy hodnotí pouze počet zameškaných hodin nebo dnů, ale již nic nevíme o důvodech neprítomnosti (Balfanz, 2016). Ideální by tak nejspís bylo sledovat oba ukazatele: jak celkovou míru absence, tak záškoláctví (Gottfried, 2009).

Ve skutečnosti je problematika ještě složitější, protože žák se někdy neúčastní výuky $\mathrm{z}$ důvodů na straně školy - je s celou tř́dou nebo individuálně na akci organizované školou, reprezentuje školu apod. Pro takovou neprítomnost platí obvykle jiná pravidla pro evidenci, označuje se jako nezapočtená absence apod. Tím se dostává často mimo pozornost výzkumníků i analýz. Přitom účelnost takovýchto akcí a jejich přínos pro žákovo vzdělávání mohou být velmi různé, resp. důsledky četných nezapočtených absencí např. u sportovně nadaných žáků mohou být i negativní. Ještě další formu představuje nepřítomnost žáka $\mathrm{v}$ kmenové škole $\mathrm{z}$ důvodu jeho hospitalizace nebo pobytu v ozdravovně apod., kde může být poskytována rovněž školní výuka (školy při nemocnicích a léčebnách apod.). Také pro evidenci této nepř́ítomnosti jsou odlišná pravidla (resp. se jako absence vůbec nevykazuje). To vše ukazuje na potřebu dále se věnovat vymezení (operacionalizaci) absence pro další výzkum.

Přes zdánlivou jednoduchost otázky, kolik průměrně zameškají žáci v různých stupních škol, je volba vhodné operacionalizace nesnadná, a zřejmě proto se ukázalo velmi obtížné v literatư̌e - jak české, tak zahraniční - odpověd' vyhledat. Studie PISA nabízí (přinejmenším zdánlivě) snadno porovnatelná data $(\mathrm{OECD}$, 
2016), když byly v žákovském a ředitelském dotazníku mj. položeny tyto otázky: Jak často jsi v predchozich dvou týdnech byl za skolou? (How many times in the previous two school weeks did you skip classes?) a Nakolik ve vaši škole komplikuje výuku záškoláctví? (In your school, to what extent is the learning of students hindered by students skipping classes?). Práce $s$ dotazníkovými daty o chování žáků, at už na základě sebeposouzení, nebo hodnocení učiteli, je metodologicky obtížnější, než se může zdát (Bendl et al., 2018), a získané výsledky se rozcházejí s jinými způsoby měření docházky (Keppens, Spruyt $\&$ Dockx, 2019). Navíc nejde o údaje o celkových absencích, ale spíše o záškoláctví. Proto se jimi zde nebudeme zabývat.

V literatuře se pochopitelně věnuje velká pozornost jak př́ícinám a kontextovým faktorům, tak dopadům absence na žáka, který je ve škole neprítomen, i na ostatní spolužáky a školu (Kearney, 2008; Vauhn, Maynard \& Salas-Wright, 2013, a mnozí další). Sociologie vzdělávání se také ptá, jak se liší absence žáků v různých sociálních skupinách. Existují rovněž geograficky a regionálně podmíněné rozdíly, např. ve venkovském prostoru bývají absence menší než v městských školách (Echazarra \& Radinger, 2019). Absence má také odlišný dopad na různé skupiny obyvatel - ukazuje se totiž, že pro děti ze znevýhodněného prostředí má jejich absence ve škole horší vliv na jejich školní výsledky (Dougherty, 2018; Gershenson, Jacknowitz \& Brannegan, 2015). Abychom mohli všechny tyto a další otázky v našem prostředí více prozkoumat, potřebujeme pre- devším popsat rozsah a distribuci tohoto fenoménu $\mathrm{v}$ českých školách. Nejdříve však uvedeme dostupné poznatky o průměrné míře absencí ve dvou zahraničních vzdělávacích systémech.

\subsection{Anglie}

V Evropě se monitorováním absence i opatřeními na její snižování systematicky zabývá Spojené království. Zde se zaměříme na anglický vzdělávací systém. $V$ roce 2011 ministerstvo školství (Department of Education, 2011) změnilo definici chronické absence (persistent absence) tak, že místo dřívějších $20 \%$ a více se považovalo za hranici $15 \%$ (což odpovídá 28 zameškaným dnům). Od roku 2015 se hranice dále snížila na $10 \%$. Ve zdůvodnění se uvádí, že bylo pozdě, pokud školy začaly řešit problém, až když se žák ocitl za dřívější vyšší hranicí nebo se k ní blížil (Department of Education, 2019). Nová hranice má zajistit dřivější zásah.

Cílenými opatřeními vzdělávací politiky se daří zlepšovat docházku $\mathrm{v}$ sekundárních školách (i když v posledním sledovaném období absence opět mírně narostla). Hodnoty absence $\mathrm{v}$ primárních školách jsou sice $\mathrm{v}$ absolutních číslech nižší, ale zatím se je nedaří snižovat. $\mathrm{Na}$ druhou stranu prrístup anglických úřadů je kritizován jako př́liš drakonický (UK Administrative Justice Institute, 2019). Školy např́íklad ukládají rodinám finanční pokuty, když mají podezření, že žák je rodinou uvolňován bez závažného důvodu. Médii proběhl př́pad, kdy se rodiče úspěšně soudně bránili pokutě za to, 
že vzali žáka na týdenní zahraniční dovolenou mimo prázdniny. Soud rozhodl, že škola nepřihlédla $\mathrm{k}$ jinak bezproblémové žákově docházce. Rozsudek však vyvolal nevoli ředitelů škol; později byl také zrušen vyšším soudem (BBC, 2017). Následně se počet ukládaných pokud skoro zdvojnásobil (BBC, 2019). Negativním důsledkem používání sankcí může být např. účast nemocných žáků ve výuce. ${ }^{2}$

Ministerstvo školství každý rok zveřejňuje podrobné informace o absencích anglických žáků. Počet chronicky nepřítomných žáků $\mathrm{v}$ jednotlivých školách sleduje inspekce (Ofsted). Ve školním roce 2017/2018 se v anglických veřejných školách (primárních, sekundárních a speciálních) vzdělávalo 8,1 milionu žáků. Průměrná míra absence byla 4,8\% (v primárním vzdělávání 4,2\%, v sekundárním vzdělávání 5,5\% a ve speciálních školách 10,2\%). Více než $10 \%$ výuky zameškalo $11,2 \%$ žáků (v primárním vzdělávání $8,7 \%$, v sekundárním vzdělávání $13,9 \%$ a ve speciálních školách 29,6 \%). Nejvyšší absence měli žáci z etnických skupin v Británii označovaných jako travellers, resp. romští žáci; mezi nimi bylo také nejvíce chronicky nepřítomných žáků, naopak nejmenší absentérství vykazovali žáci čínského původu (Department of Education, 2019).

\subsection{Spojené státy americké}

V USA roste zájem o různé metriky absence $\mathrm{v}$ důsledku snahy sledovat nejen kognitivní, ale také non-kognitivní indikátory práce škol a školských distriktů. Současně se hledají systémy $\mathrm{k}$ včasnému zachycení potenciálně ohrožených či neúspěšných žáků, zejména těch, u nichž hrozí předčasné ukončení vzdělávání. Problémy s nedokončováním jsou zejména na úrovni vyššího sekundárního vzdělávání, kde asi polovina amerických středních škol takový systém implementovala (U.S. Department of Education, 2016). Uplatňují se ale i na nižších stupních vzdělávání, nebot́ rizikové jevy vedoucí ke školnímu vyvazování (disengagement; Finn, 1993) neboli odcizování žáka a školy vznikají již dříve. Přednost mají ukazatele založené na využití snadno dostupných, školou již evidovaných dat. Základem bývá sada indikátorů označovaná $\mathrm{ABC}$ (attendance, behaviour, course grades tedy docházka, chování, známky). Jde tedy o data, která jsou rutinně evidována i v českých školách. Vidíme, že monitorování celkových absencí hraje $\mathrm{v}$ americkém systému klíčovou roli. Tento př́stup nám může připomínat českou praxi, kdy jsou nápadné změny $\mathrm{v}$ chování a výkonu žáka projednávány na klasifikačních poradách. Odlišnost spatřujeme v tom, že vyhodnocování indikátorů a vyvozování opatření se v USA děje v kratších intervalech, nejčastěji je to jeden týden (skoro $v$ polovině středních škol; U.S. Department of Education, 2016).

Jako chronická absence (chronic absenteeism) se v USA obvykle označuje

\footnotetext{
${ }^{2}$ Johansen $(2018,2019)$ studoval důvody, proč jsou někteří nemocní žáci př́tomni ve škole. Takové chování může být mj. př́činou jejich pozdější dlouhodobé zdravotní absence (nebo absence jejich spolužáků).
} 
nepřítomnost ve škole, $\mathrm{v}$ důsledku které žák zamešká během školního roku $10 \%$ a více vyučování, a to $\mathrm{z}$ jakéhokoli důvo$\mathrm{du}$, a zahrnuje omluvenou i neomluvenou absenci a (dočasné) vyloučení. Ve školním roce 2015/2016 se chronická absence v USA týkala $15 \%$ žáků (asi 8 milionů). U dětí žijících v chudobě je chronické absentérství asi dvakrát až třikrát častější než $\mathrm{v}$ celé populaci. Zvýšený výskyt je pozorován rovněž u některých etnických menšin a u žáků s postižením (Chang et al., 2019).

Pokud jde o úroveň školy, nejčastěji uváděným indikátorem je podíl chronicky absentujících žáků. Pokud takových žáků je ve škole $20-29 \%$, je to považováno za vysokou úroveň absentérství; nad 30\% se mluví o extrémní úrovni. Ve školním roce 2015/2016 se čtvrtina žáků vzdělávala ve školách s vysokou nebo extrémní absencí (Chang et al., 2019).

Pokud tedy shrneme předchozí oddíl, pak se $\mathrm{v}$ současnosti sledují především celkové, nikoli jen neomluvené absence vztažené k celkové době výuky. Za mezní hodnotu pro označení žáka jako chronického absentéra se obvykle prijímá $10 \%$ zameškaných hodin nebo dnů. $\mathrm{V}$ Anglii žák průměrně zamešká asi $5 \%$ výuky a chronická absence se týká asi 11 \% žáků, ve Spojených státech asi $15 \%$ žáků.

\section{Metodologie}

V této studii nesbíráme vlastní data, ale využíváme tzv. otevřená data a administrativní mikrodata. $\mathrm{V}$ obou př́padech jde o data rutinně vytvářená státní správou nebo školami $z$ důvodů řízení a evidence v organizaci nebo v rezortu. Nejsou tedy primárně určena pro výzkumné ani statistické účely (Dvořák \& Vyhnálek, 2019), ale přesto mohou být velmi cenným zdrojem poznání.

\subsection{Otevřená data České školní inspekce}

Problematika administrativních dat souvisí s hnutím za otevřená data - je součástí úsilí o open government. Otevřená data jsou dostupná každému, zdarma, dálkově a v strojově čitelném formátu, bez omezení použití. Panuje naděje, že široká dostupnost takovýchto dat (v našem prrípadě o školství) posílí transparentnost a efektivitu vzdělávací politiky a praxe, zlepší nabídku vzdělávání i spokojenost aktérů a kvalitu jejich života (Kubáň, 2016). V rámci plnění závazků vyplývajících $\mathrm{z}$ účasti České republiky ${ }^{3} \mathrm{v}$ mezinárodní iniciativě Partnerství pro otevrené vládnutí jsou otevírány také informace o školách a školských zařízeních z informačního systému České školní inspekce. Byla mimo jiné zpř́stupněna datová sada vyplněných formulářù tzv. hospitačních záznamů, které jsou pořizovány $\mathrm{v}$ rámci prezenční formy inspekční činnosti přímo ve školách z každé navštívené vyučovací hodiny.

Pracovali jsme se souborem dat o hospitacích $\mathrm{v}$ základních školách, kde proběhla inspekce ve školním roce

\footnotetext{
${ }_{3}^{3}$ Usnesení vlády číslo 691 ze dne 14. záŕí 2011.
} 
2017/2018. Jedním z údajů, který inspektoři zaznamenávají, je počet žákủ, kteří by měli být na hodině př́tomni, a počet skutečně prítomných žáků. Data jsou před zveřejněním anonymizována (nejsou uvedeny identifikátory jednotlivých škol), uživateli je znám pouze kraj a typ zřizovatele. Vzhledem $\mathrm{k}$ tomu, že $\mathrm{v}$ souboru není uveden ani bezvýznamový identifikátor školy, nelze slučovat různé záznamy $\mathrm{z}$ téže školy nebo je porovnat mezi sebou. $V$ současnosti je inspekční cyklus šest let, můžeme tedy jen odhadnout, že záznamy pokrývají zhruba šestinu českých základních a speciálních škol.

Z celkového počtu 13337 záznamů o provedené hospitaci jsme vybrali ty, kdy byli na hodině př́tomni pouze žáci jednoho ročníku, celkem 11679 záznamů. Dále jsme vyloučili 52 záznamů, kde se nejednalo o výuku v 1.-9. ročníku (vesměs šlo o prrípravné třídy). Vyřadili jsme také dva záznamy, kde počet zapsaných žáků nebyl vyplněn. $\mathrm{V}$ takto vymezených hospitovaných tř́íách bylo zapsáno 225400 žáků, nejde však o adekvátní podíl žákovské populace, nebot některé tř́dy jsou v průběhu inspekce navštíveny, a tedy započteny, více než jednou.

\subsection{Data ze školního informačního systému pilotní školy}

Otevřená data z inspekční činnosti jsou agregovaná na úrovni tříd. Umožňují odhadnout průměrnou nepřítomnost $\mathrm{v}$ jednom časovém bodě $\mathrm{v}$ hospitovaných tř́dách, ale neposkytují žádnou informaci o tom, zda $\mathrm{k}$ ní přispívají všichni žáci stejně, nebo zda jsou někteří jedinci chronickými absentéry. Tuto informaci můžeme získat jedině z mikrodat, kde se pro výzkumné nebo monitorovací účely využívají původní, popř. propojená data o každé jednotce - tedy o každém žákovi. Pro výzkumné použití jsou dodatečně anonymizovaná $\mathrm{v}$ souladu $\mathrm{s}$ legislativou na ochranu dat. To umožňuje - na rozdíl od běžně uvolňovaných dat - podrobnější třídění podle potřeb výzkumníka, většinou však neumožňuje propojení s jinými daty.

Př́stup $\mathrm{k}$ administrativním datům by měl být $\mathrm{v}$ současné době teoreticky velmi usnadněn tím, že školy obecně používají informační systémy. $\mathrm{Na}$ druhou stranu dostupnost a zejména propojování dat jsou omezeny legislativními bariérami (GDPR). Scharleová (2018) připomíná, že $\mathrm{v}$ praxi se na cestě $\mathrm{k}$ administrativním datům můžeme setkat $s$ řadou dalších překážek - přestože náklady na př́ípravu datových souborů jsou obvykle velmi malé ve srovnání s novým sběrem dat, anonymizace vyžaduje čas správců informačních programů ve škole, a to limituje jejich ochotu data poskytnout.

V našem výzkumu jsme zatím získali mikrodata o absencích z pěti různých základních škol. Ačkoli tato data mají značný výzkumný potenciál a budeme je dále zpracovávat, jen $\mathrm{v}$ jednom př́padě bylo možné absolutní počty zameškaných hodin prevést na relativní míru absence, protože nám škola pro každého žáka poskytla také údaj o celkovém počtu hodin výuky, kterých se žák mohl zúčastnit (viz diskuse). Tato data jsme proto použili jako 
pilotní. Jde o velkou úplnou základní školu se skoro tisícem žáků $\mathrm{v}$ předměstském prostředí na okraji velkoměsta, bez výraznějších sociálních problémů.

\subsection{Zpracování dat}

Naše práce si klade za cíl první exploraci tématu. Provádíme proto pouze prostý popis získaných dat. Jsme si vědomi, že nemůžeme očekávat symetrické rozdělení dat, přesto - kvůli srovnatelnosti se zahraničními informacemi - charakterizujeme sledované veličiny pomocí průměrů. Neznáme způsob, jakým byl vybrán soubor škol navštívených Českou školní inspekcí ve sledovaném období; neužíváme proto postupy konfirmační analýzy. Lze předpokládat, že v delším horizontu by bylo možné získat $\mathrm{z}$ tohoto zdroje úplná data o českých školách charakteru censu.

\subsection{Etické aspekty}

Argumentujeme, že je třeba pro výzkumné i praktické účely více využívat a analyzovat mikrodata, tedy data $o$ jednotlivých žácích, popř. i data na mezoúrovni, tedy data o individuálních školách. Při tom však narážíme na klasické etické dilema, kdy se do konfliktu dostávají dva dobré cíle: snaha výzkumně popsat rizikové žáky (nebo školy) a v praxi je včas zachytit, a na druhé straně potřeba chránit citlivá data o jedincích, popř. neposilovat stigmatizaci konkrétních škol nebo skupin žáků. Neplatí zde absolutní morální pravidla, nebot přístup $\mathrm{k}$ těmto otázkám se $\mathrm{v}$ různých zemích velmi od- lišuje. V citovaných případech Spojených států amerických a Spojeného království jsou kupř́íkladu průměrná data o absencích zveřejňována zvlášt́ pro různé etnické či rasové (sic!) skupiny (National Center for Education Statistics, 1996). To je praxe, která je za současných podmínek u nás eticky i technicky nepředstavitelná.

Výzkum jsme zahájili v době, kdy ještě na našem pracovišti nebyla ustavena komise pro etiku ve výzkumu, byli jsme si však vědomi nutnosti dodržet normy ochrany dat a etiky výzkumu. Pro zodpovězení našich výzkumných otázek při tom postačovala data anonymizovaná. Takováto data již nespadají do kategorie osobních dat, což zjednodušuje práci s nimi. Recitál 50 obecného nařízení o ochraně osobních údajů (GDPR) také do tzv. slučitelného účelu zpracování řadí použití již existujících dat pro účely výzkumu. Otevřená data České školní inspekce jsou poskytovatelem anonymizována před zveřejněním. Mikrodata anonymizovali školní správci dat na vyžádání výzkumníků bez nároku na odměnu. Díky radám učitelů poveřených správou informačních systémů jsme postupně dokázali přesněji specifikovat formát dat, která potřebujeme, a tím zefektivnit postup, jak je generovat. Oslovené školy při tom projevily velkou vstřícnost. Ukázalo se, že ze stávajících elektronických systémů nejčastěji používaných pro evidenci docházky pro zkušené pracovníky škol není př́liš obtížné data exportovat a pak anonymizovat. Vedení škol výzkum absence zaujal, považovali ho za hodný podpory a sdělili nám řadu zkušeností, které budeme dále analyzovat kvalitativně. 


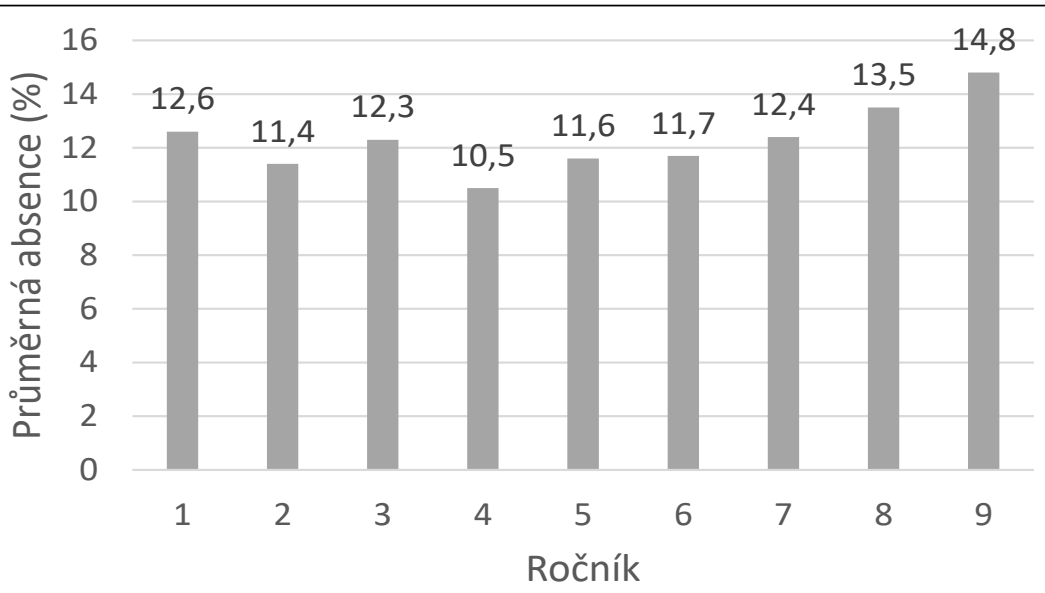

Obr. 1. Průměrná míra absence v hospitovaných hodinách podle ročníků, školní rok 2017/2018 (zdroj dat: ČŠI, zpracování autoři)

Je nepochybné, že existence velkých souborů relativně dostupných administrativních dat, kam patří i data z elektronických třídních knih a dalších výkazů, $\mathrm{v}$ prríštích letech ovlivní způsob provádění sociálněvědního bádání. Ruku v ruce $s$ tím bude potřeba dále precizovat etické, právní a technické aspekty provádění výzkumu. Tomu odpovídá i posun v institucionalizaci etického posuzování výzkumu i podpory výzkumné integrity, jehož jsme $\mathrm{v}$ posledních letech svědky.

\section{VÝSLEDKY}

V této části uvedeme údaje o průměrné celkové absenci jak pro soubor hospitovaných škol, tak pro pilotní školu.

\subsection{Průměrná míra zameškaných hodin}

Obrázek 1 uvádí data o průměrné docházce Českou školní inspekcí hospitovaných hodin podle postupného ročníku. Pokud jde o předměty, pak nejvyšší docházku, kolem 90\%, měly esteticko-výchovné předměty a výchova ke zdraví (ta však byla $\mathrm{v}$ datech málo zastoupená). Naopak nejvyšší absence, kolem 15-20\%, byly $\mathrm{v}$ hodinách jiných cizích jazyků než angličtiny, což vysvětlujeme zejména tím, že jsou vyučovány ve vyšších ročnících, kde jsou celkově absence vyšší. $Z$ předmětů, které jsou pravděpodobně zastoupeny $\mathrm{v}$ učebním plánu všech ročníků, byla docházka nejhorší v tělesné výchově (86 \%). ${ }^{4}$

$\overline{{ }^{4}}$ Nebereme $\mathrm{v}$ úvahu předměty speciálněpedagogické péče nebo speciální vyučovací předměty, kde průměrně nebyla prýítomna třetina žáků. 
Tab. 2. Regionální rozdíly v docházce žáků základních škol (zdroj dat: ČŠI)

\begin{tabular}{|c|c|}
\hline Kraj & Docházka (\%) \\
\hline Ústecký & 85,5 \\
\hline Středočeský & 85,7 \\
\hline Karlovarský & 86,2 \\
\hline Hl. m. Praha & 86,2 \\
\hline Jihomoravský & 86,8 \\
\hline Liberecký & 87,1 \\
\hline Plzeňský & 87,1 \\
\hline Královéhradecký & 87,2 \\
\hline Moravskoslezský & 88,4 \\
\hline Olomoucký & 88,7 \\
\hline Jihočeský & 89,1 \\
\hline Vysočina & 90,0 \\
\hline Pardubický & 90,3 \\
\hline Zlínský & 91,1 \\
\hline
\end{tabular}

Použitý zpo̊sob anonymizace inspekčních dat neumožnil provést analýzu jinak než na krajské úrovni (tab. 2). Průměrné absence se jeví nižší v krajích České republiky $s$ menším podílem městského obyvatelstva. To odpovídá zjištěním z šetření PISA, podle nichž obecně žáci ve městech přiznávají vyšší míru záškoláctví a ředitelé městských škol uvádějí vyšší problémy v jeho důsledku (Echazarra \& Radinger, 2019, s. 29).

Údaje o průměrné absenci podle ročníku z inspekčního informačního systému můžeme porovnat s daty z pilotní školy (tab. 3). Průměrná míra absencí $\mathrm{v}$ pilotní škole $(11,4 \%)$ je blízko průměrné hodnotě pro celý soubor hospitovaných hodin (12,3\%). Lze tedy říci, že v pilotním výzkumu jde o školu typickou. Jak v celostátních datech, tak v pilotní škole má průběh míry absence tvar písmene $U$, resp. J: pokles absencí ve středním školním věku je následován

Tab. 3. Průměrná míra celkové absence v jednotlivých ročnících pilotní školy

\begin{tabular}{|l|c|c|c|c|}
\hline \multirow{2}{*}{ Ročník } & \multirow{2}{*}{ Počet žáků } & \multicolumn{2}{|c|}{ Průměrný počet hodin } & \multirow{2}{*}{$\begin{array}{c}\text { Podíl absencí } \\
\text { (\%) }\end{array}$} \\
\cline { 3 - 4 } & & odučeno & zameškáno & 10,0 \\
\hline $\mathbf{1}$ & 147 & 766,1 & 76,4 & 10,7 \\
\hline $\mathbf{2}$ & 144 & 803,8 & 85,7 & 9,1 \\
\hline $\mathbf{3}$ & 149 & 883,8 & 80,0 & 8,9 \\
\hline $\mathbf{4}$ & 145 & 943,1 & 84,2 & 10,8 \\
\hline $\mathbf{6}$ & 124 & 985,0 & 106,5 & 13,1 \\
\hline $\mathbf{7}$ & 59 & 1046,5 & 136,8 & 12,7 \\
\hline $\mathbf{8}$ & 67 & 1134,0 & 143,8 & 14,8 \\
\hline $\mathbf{9}$ & 62 & 1198,5 & 177,3 & 18,6 \\
\hline Celkem & 60 & 1229,0 & 228,0 & 11,4 \\
\hline
\end{tabular}


poměrně strmým vzestupem $\mathrm{v}$ posledních ročnících základního vzdělávání.

\subsection{Chronické absence}

Data České školní inspekce neumožňují stanovit hodnoty indikátoru, který se v současné době považuje za nejvhodnější - tedy podílu chronicky absentujících žáků. K tomu jsou nutná mikrodata, která jsou dostupná v informačních systémech škol. Pro první stupeň pilotní školy, kde rozdíly v průměrné absenci mezi ročníky byly malé (tab. 3), jsme vytvořili souhrnný histogram popisující rozdělení počtu žáků $s$ různými úrovněmi absencí (obr. 2) na základě dat školního informačního systému. Pro jednotlivé ročníky druhého stupně uvádí odpovídající údaje tabulka 4.
Na druhém stupni této běžné, v podstatě bezproblémové základní školy by bezmála polovina žáků šestých a sedmých ročníků byla $\mathrm{v}$ zahraničí považována za chronické absentéry. $\mathrm{V}$ osmém ročníku už se jedná o $58 \%$ a v devátém ročníku má celých $83 \%$ žáků $s$ více než $10 \%$ zameškaných hodin. Situace na prvním stupni není o mnoho lepší (chronickými absentéry by bylo $44 \%$ žáků).

\section{DisKuSE}

Naším cílem bylo představit různé způsoby operacionalizace jevu absence a pokusit se odhadnout hodnoty príslušných indikátorů pro české prostředí. Jak bylo uvedeno, je překvapivě obtížné zjistit srovnatelné hodnoty pro zahraniční vzdělávací systémy. Citované údaje za Anglii

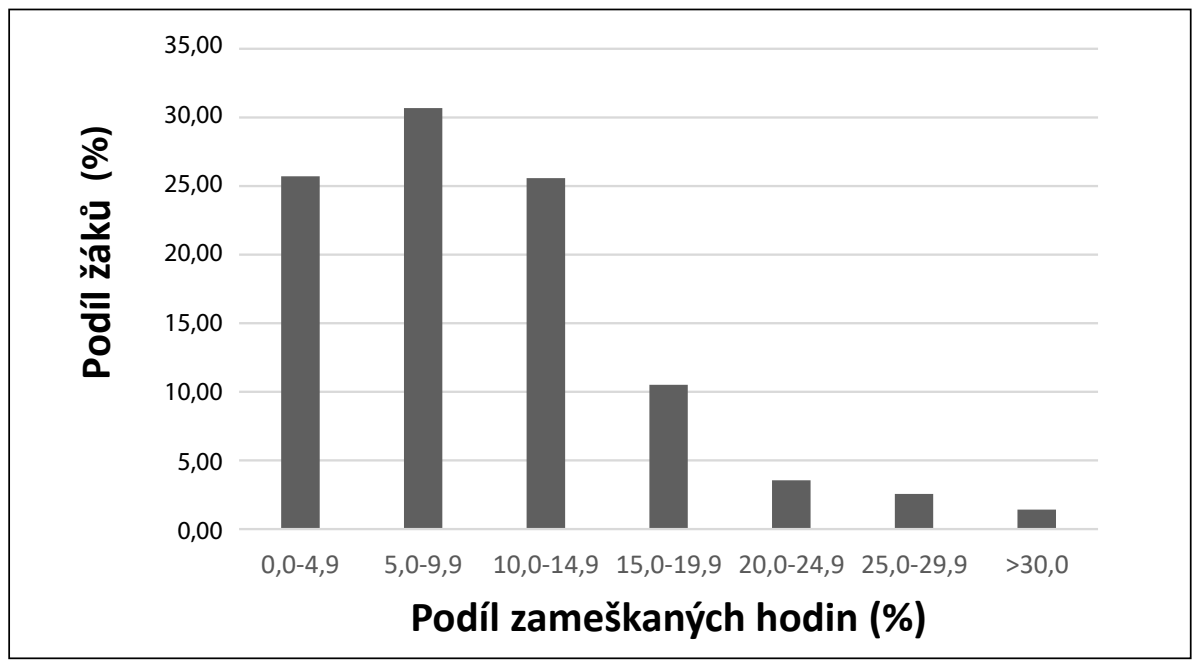

Obr. 2. Podíly žáků s různou mírou absence na prvním stupni pilotní základní školy 
Tab. 4. Podíly žáků s různou mírou absence na druhém stupni pilotní základní školy

\begin{tabular}{|l|c|c|c|c|c|c|c|}
\hline \multirow{2}{*}{ Ročník } & \multicolumn{7}{|c|}{ Podíl žáků s různou mírou absencí (\%) } \\
\cline { 2 - 8 } & $0,0-4,9$ & $5,0-9,9$ & $10,0-14,9$ & $15,0-19,9$ & $20,0-24,9$ & $25,0-29,9$ & $>30,0$ \\
\hline $\mathbf{6}$ & 23,7 & 27,1 & 18,6 & 6,8 & 10,2 & 6,8 & 6,8 \\
\hline 7 & 12,1 & 39,4 & 19,7 & 12,1 & 6,1 & 6,1 & 4,5 \\
\hline $\mathbf{8}$ & 12,9 & 29,0 & 16,1 & 16,1 & 12,9 & 6,5 & 6,5 \\
\hline $\mathbf{9}$ & 1,7 & 15,0 & 21,7 & 21,7 & 21,7 & 8,3 & 10,0 \\
\hline
\end{tabular}

jsou méně než poloviční. Jak jsme uvedli, anglická vzdělávací politika a praxe se na absence dlouhodobě zaměruje, někdy až za cenu určitých excesů a neúměrné tvrdosti vưči rodičům a žákům. Přesto je potřeba si položit otázku, zda česká praxe $\mathrm{k}$ absencím nepřistupuje př́li iš liberálně, anebo dokonce nebyla donedávna lhostejná $\mathrm{k}$ signálům o problémech žáků (přitom celkový počet vyučovacích hodin v českých školách nepatří k nejvyšším). Přes omezenou použitelnost historických dat se zdá, že celkové absence českých žáků jsou dnes také vyšší než před šedesáti lety (Chlup, 1962), navzdory nesporným pokrokům ve zdravotní péči. Vzestupný trend celkového podílu záškoláků a absentérů na druhém stupni základní školy může ovšem zakrývat odlišné trajektorie vývoje chování podskupin žáků (Chin-Chih, Culhane \& Metraux, 2016; Schoeneberger, 2012).

Naše velmi předběžné výsledky dokládají, že téma absencí českých žáků by mělo být dále zkoumáno pro svou významnost pro školskou politiku a v neposlední řadě i proto, že vysoká míra absencí, pokud se potvrdí, by mohla signalizovat problematické postoje českých žáků a jejich rodičů ke škole, ale i nesprávné prrístupy některých škol nebo dalších aktérů $\mathrm{k}$ absentujícím žá- kům. Na druhou stranu, nedomníváme se, že je třeba hned volat po zpřísnění sankcí vủči absentérům nebo podobných opatřeních, dokud o problému neshromáždíme více informací nebo nebudeme řešit primární př́ičiny související se skutečnou nebo žáky vnímanou užitečností školy. Nevhodná opatření by mohla být i kontraproduktivní. Obecně vhodnost a účinnost různých preventivních či represivních opatření je v zahraniční literatuře podrobně diskutována (např. Sutphen, Ford \& Flaherty, 2010), tato zjištění by však bylo třeba výzkumně ověrit $\mathrm{v}$ našich podmínkách.

Práce s administrativními nebo otevřenými daty má řadu výhod, avšak neumožňuje výzkumníkovi kontrolu nad tím, jaké informace jsou sbírány a jak jsou anonymizovány. Současný způsob zveřejnění inspekčních dat je na jednu stranu třeba ocenit jako krok správným směrem, který vytváŕí prostor pro určité typy analýz. Na druhou stranu $\mathrm{v}$ současné podobě neumožňuje odpovědět na řadu důležitých otázek, mezi nimi např. na rozdíly $\mathrm{v}$ absencích mezi jednotlivými školami.

I v České republice se chronické absentérství a záškoláctví s vysokou pravděpodobností budou koncentrovat do určitých škol, lokalit nebo regionů (Čada, 2015). Podle analytiků 
České školní inspekce, kteří pracovali s větším souborem hospitačních záznamů před jejich anonymizací, může být průměrný počet zameškaných hodin přepočtený na žáka ve vyloučených lokalitách skoro dvojnásobný oproti celé populaci. Podíl žáků, kteří mají neomluvené hodiny, je ve školách ve vyloučených lokalitách několikanásobně vyšší (Havličková \& Greger, ústní sdělení). Lze doufat, že do budoucna neporoste jen objem otevřených dat, ale že také budou zveřejňována ve formě, která umožní jejich komplexnější analýzy a propojování s jinými databázemi. Čeští ŕeditelé škol ve vyloučených lokalitách uvádějí, že klíčovým problémem omezujícím výuku jsou vysoké absence žáků (omluvené) následované záškoláctvím, pozdními prríchody žáků do školy, popř. neúčastí žáků na povinných akcích školy (Česká školní inspekce, 2015, s. 4). I v našem prostředí se tedy potvrzuje, že zjevné záškoláctví představuje jen jednu část problémů spojených s docházkou (Birioukov, 2016).

Naše snaha doplnit tyto informace daty z jiných zdrojů, nap̌r. z výročních zpráv škol zveřejňovaných na internetu, doposud nebyla př́iliš úspěšná. Absolutní počty zameškaných hodin, které bývají uváděny $\mathrm{v}$ některých výročních zprávách, jsou totiž problematickým indikátorem, jak jsme ukázali výše. Pokud sledujeme pouze absolutní počty zameškaných hodin, zkreslí evidenci např. žáci, kteří odešli v průběhu pololetí (popř. ke vzdělávání vůbec nenastoupili, ale přestup formálně proběhl později), žáci, kteří jsou ve škole evidováni podle $₫ 38$, ale de facto se vzdělávají jinde apod. Při stejném počtu zameškaných dní mají žáci různých ročníků jiný počet zameškaných hodin, takže agregovaná data za ce- lou školu mohou při stejné míre absence záviset na podílu žáků v různých ročnících.

Velký potenciál spatřujeme $\mathrm{v}$ datech ze školních informačních systémů, pokud by se vyřešil způsob takové jejich anonymizace, která by současně umožňovala longitudinální sledování po celou dobu školní docházky jednotlivými ročníky a propojení s jinými informacemi o žákovi. Tuto podmínku by splňoval bezvýznamový identifikátor žáka. Longitudinální data by mj. umožnila odlišit různé trajektorie vývoje (rizikového) chování žáků a možná i jejich postojů ke škole (Chin-Chih et al., 2016; Spencer, 2009).

Když jsme v úvodu konstatovali, že Hlad’o a Šlapalová (2019), resp. Šlapalová a Hlado (2020) se zabývají absencemi ,jen“ kvalitativně, měli bychom nyní dodat, že naše pouze kvantitativní analýza pochopitelně rovněž ukazuje své jasné limity a bude potřeba ji doplnit dalšími šetřeními ve školách nebo komunitách, která by pomohla interpretovat naše zjištění. Nejbližším následujícím krokem by měla být deskriptivní analýza na větším, pokud možno reprezentativním souboru základních škol a na dalších typech škol (stř̌ední školy, speciální školy). Dále potřebujeme více vědět $o$ prrícinách vysokých absencí českých žáků a o jejich dopadech. Kromě „tvrdých dat" je také potřeba zkoumat perspektivu různých aktérů, jako jsou žáci, rodiče, učitelé a ředitelé škol (Finning et al., 2018, 2019b). V neposlední řadě bychom se mèli zajímat také o to, jak školy poskytují podporu žákům $s$ velkým počtem zameškaných hodin a jak lze absencím prredcházet (Gentle-Genitty, Taylor \& Renguette, 2020; Kearney et al., 2019b; Strand \& Granlund, 2014). 


\section{ZÁVĚR}

Hlavním závěrem, který bychom chtěli zdůraznit, je nedostatečnost v Česku převažujícího způsobu sledování absencí prostřednictvím absolutního počtu zameškaných hodin (nebo dokonce jen neomluvených hodin). $\mathrm{Na}$ úrovni žáka je vhodnější sledovat percentuální podíl všech zameškaných hodin (dnů) k celkovému času výuky, na úrovni školy pak podíl chronicky absentujících žáků (tj. s podílem absencí vyšším než stanovená mez). Absence by neměla být vnímána jen z hlediska záśkoláctví nebo jako problém koncentrovaný pouze do vyloučených lokalit. Druhým, s tím souvisejícím závěrem je překvapivě vysoká míra absencí v celé populaci českých žáků ve srovnání např. s Anglií, kde se tato problematika dlouhodobě řeší. Data, z nichž v tomto článku vycházíme, však jsou značně omezená a mají jen pilotní charakter. Třetím závěrem proto je nezbytnost dalšího výzkumu různých aspektů docházky a absencí; některá možná témata jsme naznačili výše. Konečně za čtvrté chápeme hlasy ve veřejném prostoru, které varují před ukvapeným přijímáním efektních opatření $\mathrm{k}$ řešení dlouho zanedbaného stavu - na druhou stranu další odkládání řešení jen zvyšuje frustraci části pedagogů i rodičů, kteří se musí denně vyrovnávat $s$ důsledky dosavadního laxního př́ístupu k plnění školní docházky.

\section{Poděkování}

Děkujeme vedeni škol zúčastněných ve výzkumu a jejich správcuim informačnich systémü, kterí pro nás prippravili soubory mikrodat. Děkujeme Ceské školni inspekci za zveřejnèni dat z inspekční činnosti. Děkujeme rovněž obèma recenzentům za jejich pripominky, které prispěly ke zpřesnéni a zpřehlednèni textu.

\section{Literatura}

Balfanz, R. (2016). Missing school matters. Phi Delta Kapa, 98(2), 8-13.

BBC. (2017, 23. června). Isle of Wight term-time holiday dad Jon Platt guilty. Dostupné z www.bbc.com/news

BBC. (2019, 21. března). School holiday fines: Parents hit by penalties rise 93\%. Dostupné z www.bbc.com/news

Bendl, S., Voňková, H., Papajoanu, O., \& Vaňkátová, E. (2018). An examination of different methodological approaches in student school behavior research: The issue of the incomparability of student self-assessments. Pedagogická orientace, 28(4), 627-662.

Birioukov, A. (2016). Beyond the excused/unexcused absence binary: Classifying absenteeism through a voluntary/involuntary absence framework. Educational Review, 68(3), 340-357.

Čada, K. (Ed.). (2015). Analýza sociálnè vyloučených lokalit v $\check{C} R$. Praha: GAC s.r.o. Dostupné z http://irop.mmr.cz

Česká školní inspekce. (2015). Kvalita vzděláváni v sociálně vyloučených lokalitách. Tematická zpráva. Praha: ČŠI. 
Department of Education. (2011). Persistent absence: Government changes definition to deal with reality of pupil absenteeism in schools. Dostupné z www.gov.uk/government

Department of Education. (2019). Absence from school. Dostupné z www.ethnicity-facts-figures.service.gov.uk Dougherty, S. M. (2018). How measurement and modeling of attendance matter to assessing dimensions of inequality. Journal of Education for Students Placed at Risk, 23(1-2), 9-23.

Dvořák, D., \& Vyhnálek, J. (2019). Meziškolní mobilita žáků středních škol v České republice. Pedagogika, 69(2), 131-146.

Echazarra, A., \& Radinger, T. (2019). Learning in rural schools: Insights from PISA, TALIS and the literature. OECD Education Working Papers 196. Paris: OECD Publishing.

Finn, J. D. (1993). School engagement and students at risk. Washington, DC: U.S. Dept. of Education, Office of Educational Research and Improvement, National Center for Education Statistics.

Finning, K., Harvey, K., Moore, D., Ford, T., Davis, B., \& Waite, P. (2018). Secondary school educational practitioners' experiences of school attendance problems and interventions to address them: a qualitative study. Emotional and Behavioural Difficulties, 23(2), 213-225.

Finning, K., Ukoumunne, O. C., Ford, T., et al. (2019a). The association between child and adolescent depression and poor attendance at school: a systematic review and meta-analysis. Journal of Affective Disorders, 245, 928-938.

Finning, K., Waite, P., Harvey, K., Moore, D., Davis, B., \& Ford, T. (2019b). Secondary school practitioners' beliefs about risk factors for school attendance problems: a qualitative study, Emotional and Behavioural Difficulties, 25(1), 15-28.

Gentle-Genitty C., Taylor, J., \& Renguette, C. (2020). A change in the frame: From absenteeism to attendance. Frontiers in Education, 4, 161.

Gershenson, S., Jacknowitz, A., \& Brannegan, A. (2015). Are student absences worth the worry in U.S. primary schools? IZA Discussion Paper No. 9558. Dostupné z https://ssrn.com

Gottfried, M. A. (2009). Excused versus unexcused: How student absences in elementary school affect academic achievement. Educational Evaluation and Policy Analysis, 31(4), 392-415.

Hlado, P., \& Šlapalová, K. (2019). „Už to dál nešlo“ - meziškolní mobilita ve středním odborném vzdělávání zpětným pohledem žáků. Pedagogika, 69(3), 147-164.

Hromková, D., \& Janouš, V. (2020). Pojdte do školy, prosí děti ředitelka. MF Dnes, 21. února.

Chang, H. N., Osher, D., Schanfield, M., Sundius, J., \& Bauer, L. (2019). Using chronic absence data to improve conditions for learning. Dostupné z https://www.attendanceworks.org

Chin-Chih, C., Culhane, D. P., \& Metraux, S. (2016). The heterogenity of truancy among urban middle school students: A latent class growth analysis. Journal of Child and Family Studies, 25, 1066-1075.

Chlup, M. (1962). Absence žactva všeobecně vzdělávací školy. Pedagogika, 12(5), 577-582.

Johansen, V. (2018). Motives for sickness presence among students at secondary school: A crosssectional study in five European countries. BMJ Open; 8:e019337.

Johansen, V. (2019). A panel study of sickness presence and sickness absence among secondary school students. International Journal of Occupational Medicine and Environmental Health, 32(6), 797-804.

Kašpárková, S. (2009). Pedagogická diagnostika žáka a třidy. Univerzita Tomáše Bati ve Zlíně. 
Kearney, C. (2008). School absenteeism and school refusal behaviour in youth: A contemporary review. Clinical Psychology Review, 28, 451-471.

Kearney, C. A., Gonzalvez, C., Graczyk, P. A., \& Fornander, M. J. (2019a). Reconciling contemporary approaches to school attendance and school absenteeism: Toward promotion and nimble response, global policy review and implementation, and future adaptability (Part 1). Frontiers in Psychology, 10, 2222.

Kearney, C. A., Gonzálvez, C., Graczyk, P. A., \& Fornander, M. J. (2019b). Reconciling contemporary approaches to school attendance and school absenteeism: Toward promotion and nimble response, global policy review and implementation, and future adaptability (Part 2). Frontiers in Psychology, 10, 2605.

Keppens, G., Spruyt, B., \& Dockx, J. (2019). Measuring school absenteeism: Administrative attendance data collected by schools differ from self-reports in systematic ways. Frontiers in Psychology, 10, 2623.

Knecht, P. (2014). Př́iležitosti k učení: odlišná/různá pojetí konceptu a jeho výzkumné využití. Pedagogická orientace, 24(2), 163-184.

Kubáň, M. (2016, říjen). Otevřená data v České republice a v zahranič̌i. Předneseno na Semináři ÚV ČR dne 11. 10 2016. Dostupné z https://opendata.gov.cz

Mareš, J., \& Žofka, J. (2016). Školy při nemocnicích a dalších zdravotnických zařízeních. Československá pediatrie, 71(2), 59-67.

MŠMT. (2002). Kjednotnému postupu prí uvolñováni a omlouvání žákủ z vyučováni, prevenci a postihu záškoláctví. Metodický pokyn č. j. 10 194/2002 - 14. Dostupné z www.msmt.cz

MŠMT. (2014). Využití právnich opatřeni pri řesené problémového chováni žákư na školách. Dostupné z www.msmt.cz

MŠMT. (2017). Záškoláctví. Aktualizovaná příloha č. 11 k Metodickému doporučení k primární prevenci rizikového chování u dětí a mládeže, č. j. 21291/2010-28. Dostupné z www.msmt.cz

National Center for Education Statistics. (1996). Racial and ethnic classifications used by public schools. Dostupné z https://nces.ed.gov

OECD. (2016). PISA 2015 results (volume II). Policies and practices for successful schools. Paris: OECD Publishing.

Scharle, Á. (2018). The legal and technical solutions for administrative data access in Hungary. Vystoupení na seminári Hidden treasure for policy research: Administrative micro data 27. 4. 2018. Praha: CERGE-EI.

Schoeneberger, J. (2012). Longitudinal attendance patterns: Developing high school dropouts. The Clearing House, 85, 7-14.

Spencer, A. M. (2009). School attendance patterns, unmet educational needs, and truancy: A chronological perspective. Remedial and Special Education, 30(5), 309-319.

Strand, A. S., \& Granlund, M. (2014). The school situation for students with a high level of absenteeism in compulsory school: Is there a pattern in documented support? Scandinavian Journal of Education Research, 58(5), 551-569.

Sutphen, R. P., Ford, J., \& Flaherty, C. (2010). Truancy interventions: A review of the research literature. Research on Social Work Practice, 20, 161-171. 
Šlapalová, K., \& Hlado, P. (2020). „Už mě to tam nebavilo“ - absentérství žáků stř̌edních odborných škol v kontextu odpoutávání se od školy. Orbis scholae, 14(1).

UK Administrative Justice Institute. (2019). 'Cruel and discriminatory': New research on prosecuting parents for school absence. Dostupné z https://ukaji.org

U.S. Department of Education. (2016). Issue Brief 1: Early Warning Systems. Washington, DC: Office of Planning, Evaluation and Policy Development, Policy and Program Studies Service. Vauhn, M. G., Maynard, B. R., Salas-Wright, C. P. (2013). Prevalence and correlates of truancy in the US: Results from a national sample. Journal of Adolescence, 36(4), 767-776.

Mgr. Eva Skalová,

Ústav výzkumu a rozvoje vzdělávání, Pedagogická fakulta Univerzity Karlovy;

e-mail:eva.ska@email.cz

RNDr. Dominik Dvoŕák, Ph.D.,

Ústav výzkumu a rozvoje vzdèlávání, Pedagogická fakulta Uiverzity Karlovy;

e-mail:dominik.dvorak@pedf.cuni.cz

\section{SKALOVÁ, E., DVOŘÁK, D. How Much Time do Students Miss in the Czech Compulsory Schools?}

Aims: Students' absenteeism has serious negative consequences for both absent students and their schools. Until now, Czech school policies have mainly addressed the problem of unexcused absences (truancy) on the individual level. Many other school systems abroad, on the contrary, are concerned with monitoring, preventing, and reducing the negative impact of high levels of absenteeism, regardless of its causes. This paper has two objectives: first, we review some approaches to the definition of chronic absenteeism; second, we estimate the rate of absenteeism in Czech compulsory schools.

Methods: Open data released by the Czech School Inspectorate (data on 11625 lessons visited) and microdata from a pilot school $(N=957$ students) was used.

Results: Our exploratory analysis suggests that both the average absence rate (12\% in primary grades and $13 \%$ in lower secondary grades) and the share of chronically absent students are rather high in Czech primary and lower secondary schools.

Conclusions: The issue of absenteeism deserves more attention in the future, and should be explored both by researchers and school administrators and politicians. More indicators than just the absolute number of hours missed should be used for further investigation.

Keywords: absenteeism, truancy, open data, administrative data, Czech Republic. 